\title{
DETERMINING THE DYNAMIC CHARACTERISTICS OF HYDRAULIC EXCAVATORS
}

\author{
Olgica Ž. Lazarevića ${ }^{a}$ Boro M. Lazarević ${ }^{b}$ \\ a University of Defense in Belgrade, Military Academy, \\ Military Mechanical Engineering Department, Belgrade, \\ Republic of Serbia, \\ e-mail: olgica.I.novakovic@gmail.com, \\ ORCID iD: iDttp://orcid.org/0000-0001-5381-6888 \\ ${ }^{\mathrm{b}}$ China Communication Construction Company, Belgrade, \\ Republic of Serbia, \\ e-mail: boro.lazarevic92@gmail.com, \\ ORCID iD: (i)http://orcid.org/0000-0002-1563-3623
}

http://dx.doi.org/10.5937/vojtehg66-14400

FIELD: Construction Engineering

ARTCLE TYPE: Original Scientific Article ARTICLE LANGUAGE: English

\section{Summary:}

This paper deals with the research into the dynamic characteristics of hydraulic excavators i.e. natural frequencies and movements. The way hydraulic excavators work is described by the mathematical model of six generalized coordinates based on the Lagrange equations of the second kind. The obtained mathematical model of the excavator system represents the system of six nonlinear, nonhomogeneous differential equations of the second kind. By simulating real parameter values, we managed to obtain the functions of movement and their natural frequency changes within the allowed degrees of freedom, making it possible to examine the nature and intensity of those movements and the impacts of these parameteres on excavator operators as well as on excavator construction optimisation.

Key words: hydraulic excavator, dynamic characteristics, mathematical model, natural frequencies, movement. 


\section{Introduction}

Excavators are machines used for up to category four soil excavation and for transporting the excavated soil to a landfill or to some means of transport. They belong to the group of mobile machines. By the way they work, they can be continuous and cyclic machines. Soil excavation can be done both on land and under water. The research deals with the hydraulic wheel excavator BTH-600. Excavators are primarily used for excavating the soil with cyclic work.

The research based on both theory and experiments proved that hydraulic excavators, especially when in an open configuration position, behave as oscillation systems while transporting or unloading the soil. That is why the stability of the balance system position is analysed by the dynamic actuation of the system.

In the available reference books (Janošević, 1997), (Holclajtner et al, 2010, pp.5-25), (Lazarević et al, 2008), (Frimpong et al, 2008, pp.20-29), (Vähä \& Skibniewski, 1993, pp.148-158), (Lazarević et al, 2014), the dynamic behaviour of excavators is analysed by maximum five degrees of freedom. However, from the construction itself, together with the way excavators work, it is quite natural for the model space movement to be expanded by one more degree of freedom, that is by revolving around the transverse main central axis of the undercarriage inertia, which has been done in this work.

\section{Mechanical-dynamic model of excavators}

A mechanical model of hydraulic excavators (Figure 1) consists of undercarriage (1), rotary link (platform) (2) and manipulators $(3,4,5)$. The lower part of the excavator, the undercarriage, may be placed on caterpillars, pneumatics or on a floating object. The elements of the subsystem for transferring the power and the elements of the subsystem for transferring the signal are placed on the rotary link (the platform). The plane of digging and the plane of unloading are decided by rotating the rotary link (platform) in relation to the basic undercarriage. The basic and rotary links are connected with a joint in the shape of a radial axial bearing and they form the basis or the excavator machine (Lazarević, 2003). 


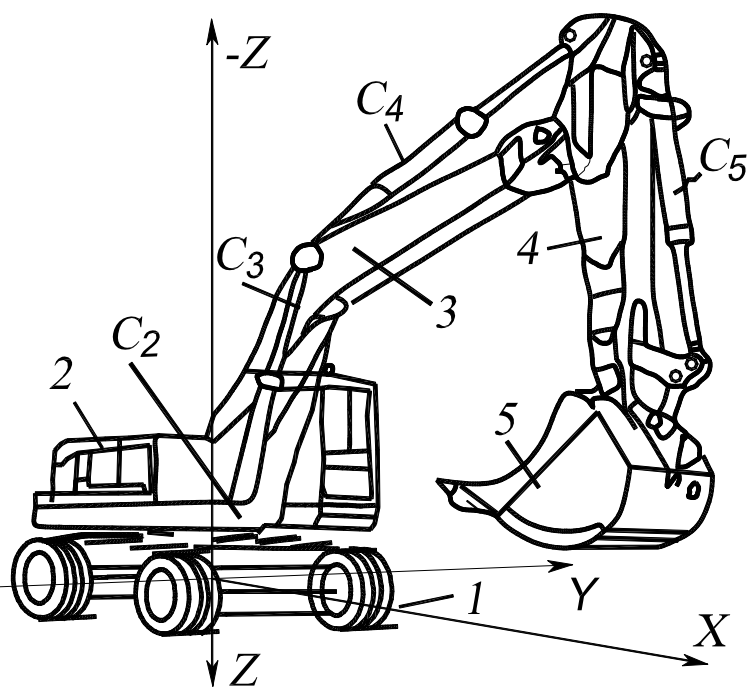

Figure 1 - Physical model of a hydraulic BTH-600 excavator: 1 - undercarriage (pneumatics), 2 - rotary link (platform), 3 - boom, 4 - arm (stick), 5 - bucket Puс. 1 - Механическая модель гидравлического экскаватора ВТН-600: - пневмоколесное ходовое устройство, 2 - поворотная платформа 3 - стрела, 4 - рукоять, 5 - ковш

Слика 1 - Механички модел хидрауличког багера ВТН-600:

1 - ослоно-кретни члан (пнеуматици), 2 - обртни члан (платформа), 3 - стрела, 4 - рука (држач), 5 - кашика 
When describing the movement of the observed system (Figure1 and Figure 2) the following assumptions were taken into account:

- Dynamic model of the excavator is a non-conservative system with stationary and ideal links,

- Small system oscillations around the stable balance position are observed,

- Excavator backing has the elastic and damping properties,

- Parts of the excavator kinematic chain are rigid bodies,

- Due to oil viscosity and stiffness, hydraulic actuators of the drive mechanisms are elastic and damping elements,

- Modulus of hydraulic oil stiffness is constant and independent from pressure and temperature.

\section{Generalized coordinates of the mechanical system of the hydraulic excavator}

The description of a dynamic excavator model (Figure 2) is defined by the generalized coordinates:

$$
\{q\}=\left\{z_{c} \varphi \theta \alpha \beta \gamma\right\}
$$

where:

$z_{c}$ - is the vertical displacement of the mass centre of the undercarriage,

$\varphi$ - is the angle of rotation around the longitudinal main central axis of inertia of the undercarriage,

$\theta$ - is the angle of rotation around the transversal main central axis of inertia of the undercarriage,

$\alpha$ - is the angle of manipulator boom rotation around the axis $O_{3} y_{3}$ of the joint to which the rotary link is attached;

$\beta$ - is the angle of manipulator arm rotation around the axis $O_{4} y_{4}$ of the joint in the end of the boom, and

$\gamma$ - is the angle of manipulator bucket rotation around the axis $\mathrm{O}_{5} y_{5}$ of the joint in the end of the arm.

It is assumed that the generalized coordinates of small size are measured from the position of the stable balance of the system. The critical excavator positions are analysed when the manipulator plane forms the right angle with the undercarriage longitudinal plane (Figure 3). 


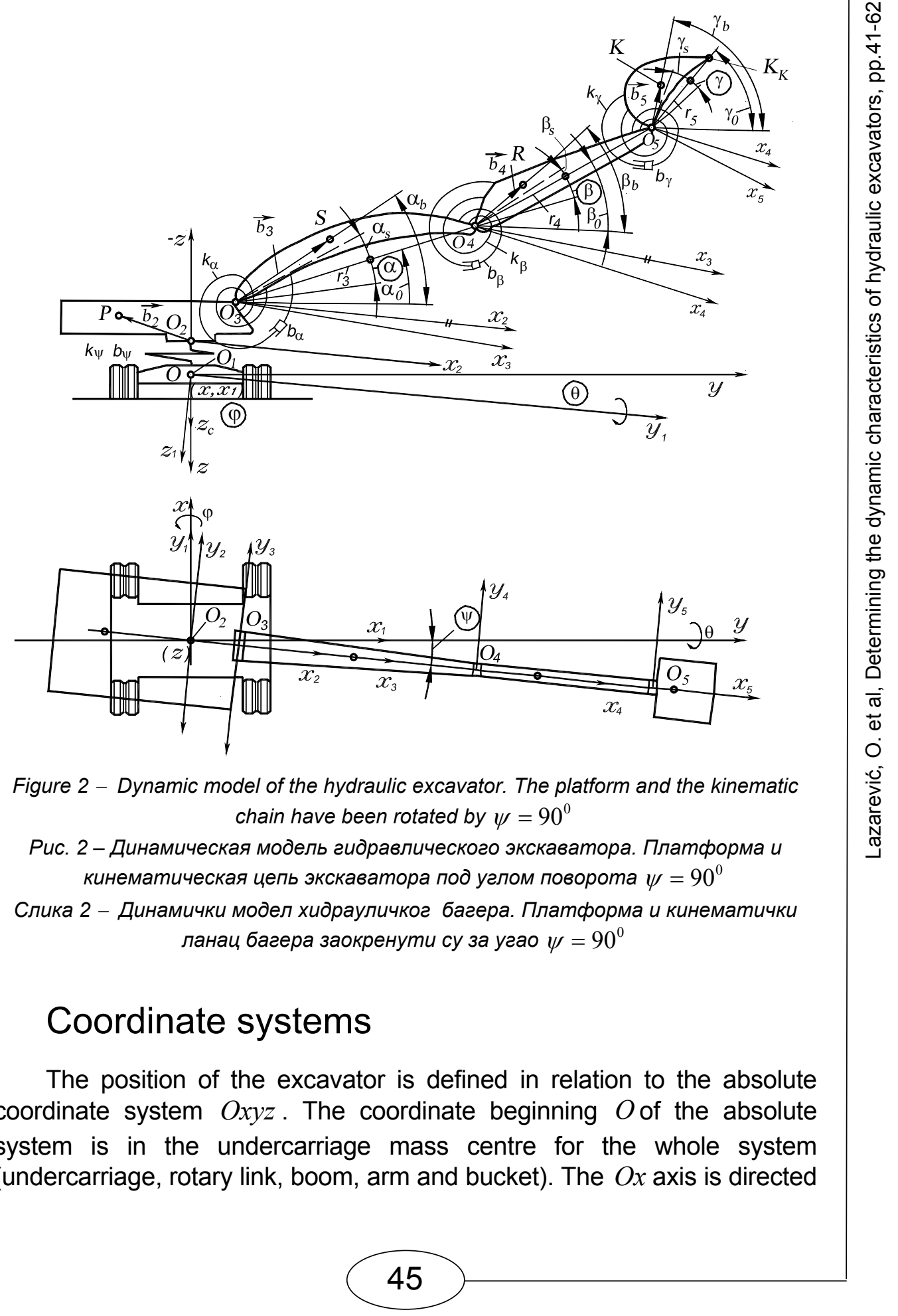


towards the longitudinal axis, while the $O y$ axis is directed towards the main transversal central axis of inertia in the position of static balance of the whole system, and the $O z$ axis is directed vertically downwards. To determine the positions of the excavator kinematic chain parts, local coordinate systems have been set up (Figure 2).

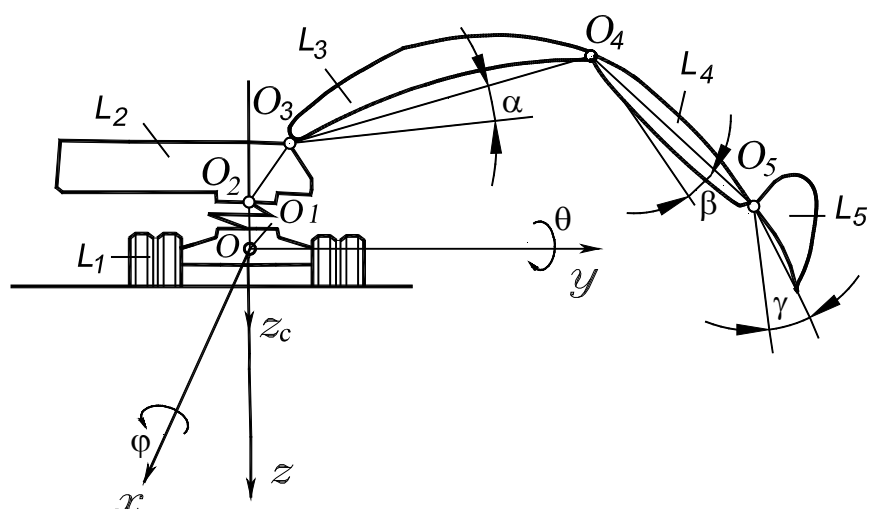

Figure 3 - Accepted generalized mechanical system coordinates Puс. 3 - Принятые обобщенные координаты механической системы Слика 3 - Усвојене генералисане координате механичког система

1. $O_{1} x_{1} y_{1} z_{1}$ - mobile coordinate system accepted for the undercarriage mass center $O_{1}$. The $O x_{1}$ axis is parallel with the longitudinal axis, the $O y_{1}$ axis is parallel with the transverse main central axis of the undercarriage inertia in the position of balance and the $O z_{1}$ axis is directed vertically downwards.

2. $\mathrm{O}_{2} x_{2} y_{2} z_{2}$ - mobile coordinate system connected with the center of the radial axial bearing $\mathrm{O}_{2}$.

3. $\mathrm{O}_{3} x_{3} y_{3} z_{3}$ - coordinate system connected with the joint center $\mathrm{O}_{3}$ and redirected by the generalized coordinate $\alpha$ in relation to the coordinate system $\mathrm{O}_{2} x_{2} y_{2} z_{2}$.

4. $O_{4} x_{4} y_{4} z_{4}$ coordinate system connected with the joint center $O_{4}$ and redirected by the generalized coordinate $\beta$ in relation to the coordinate system $\mathrm{O}_{3} x_{3} y_{3} z_{3}$. 
5. $O_{5} x_{5} y_{5} z_{5}$ coordinate system connected with the joint center $O_{5}$ and redirected by the generalized coordinate $\gamma$ in relation to the coordinate system $\mathrm{O}_{4} x_{4} y_{4} z_{4}$.

\section{Transformation matrices}

To determine the speeds of the characteristic points with such complex mechanical systems, the method applied is the one based on setting up and transforming the adequate mobile coordinate systems.

To determine vectors of the characteristic points' position in relation to the absolute coordinate system, we determined the matrices of elementary rotations around the axes $O x, O y$ and $O z$ and the transformation matrices of the immobile coordinate system Oxyz into the mobile coordinate systems $O_{i} x_{i} y_{i} z_{i}$ where $i=1-5$ as well as the matrices of mobile coordinate system transitions from one into another.

For calculating kinetic energy, it is necessary to calculate the speed of the mass centres of some hydraulic excavator parts. To be able to do this, we need the system characteristic points vector positions (Figure 4). The absolute coordinate system, the undercarriage coordinate system and the undercarriage mass center are placed together in one point, i.e. $O=O_{1}$.

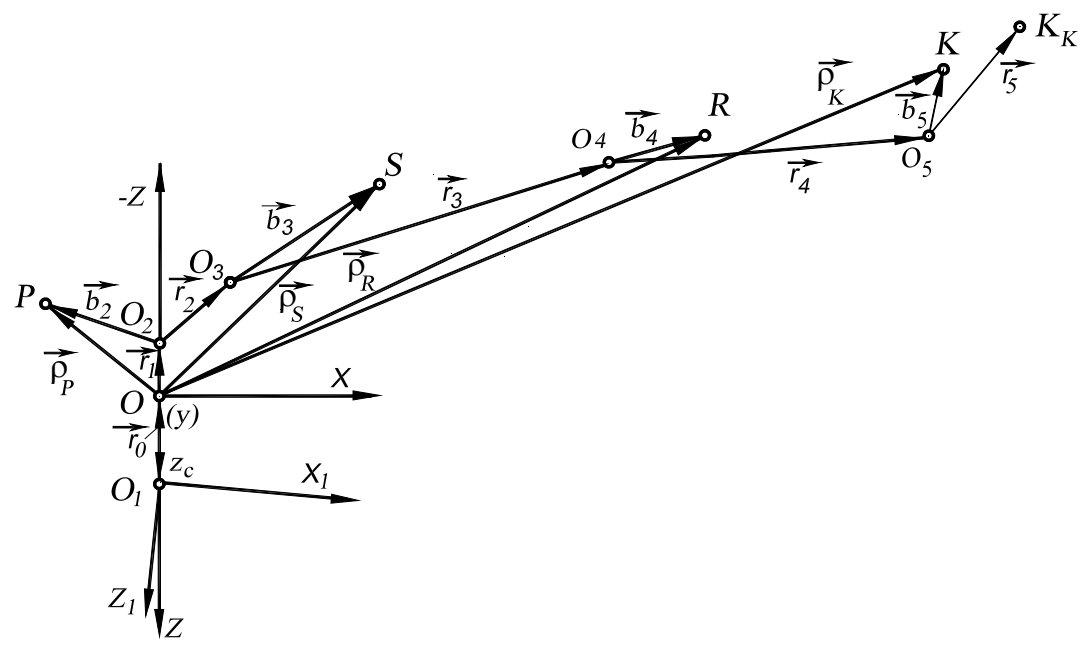

Figure 4 - Radius vectors of the characteristic system points Puc. 4 - Радиус-векторы характеристических точек системы Слика 4 - Радијус вектори карактеристичних тачака система 


\section{Mathematical excavator model}

Mathematical excavator model is based on general mechanical theorems or on applying Lagrange equations of the second kind. These are the starting assumptions taken into account when creating the mathematical model:

1. The backing and the parts of the excavator kinematic chain are modelled with rigid bodies,

2. During its manipulating tasks, the excavator work is stable with no possibility for the movements in the zero joint to appear,

3. Excavator kinematic chain is observed as an open configuration chain with its last part - the bucket - being affected by the technological resistance of digging, and

4. During its manipulating tasks, the excavator kinematic chain is affected by the forces of gravity, inertia and some external forces digging resistance.

The excavator model space is determined by the absolute coordinate system $O x y z$. The excavator backing lies in the horizontal plane $O x y$ of the absolute coordinate system, while the vertical axis $O z$ is parallel with the kinematic pair seen as the undercarriage and the rotary part. Each excavator part is determined in its local coordinate system $O_{i} x_{i} y_{i} z_{i}$ (Figures 1 and 2). The coordinate beginning of the local coordinate system is parallel with the center of the joint connecting that particular part with the previous one, while some axis are directed in such a way that they are parallel with the joint axis, and as for manipulators (boom, arm and bucket), they are parallel with the kinematic longitude of the part. For the bucket, the local coordinate system axis $O_{5} x_{5}$ goes through the joint center $O_{5}$ and through the center of the bucket cutting edge.

Differential movement equations are based on Lagrange equations of the second kind:

$$
\frac{d}{d t}\left(\frac{\partial E_{k}}{\partial \dot{q}_{r}}\right)-\frac{\partial E_{k}}{\partial q_{r}}+\frac{\partial E_{p}}{\partial q_{r}}=Q_{r}^{N}, q_{r}=z_{c}, \varphi, \theta, \alpha, \beta, \gamma, r=1,2,3,4,5,6
$$

where:

$E_{k}$ - is system kinetic energy,

$E_{p}$ - is system potential energy,

$Q_{r}^{N}$ - is generalized forces. 


\section{Resolving the systems of differential equations}

The presented mathematical model represents the system of six nonlinear, nonhomogeneous differential equations of the second kind that was resolved by using discrete numerical methods and packets in the MATLAB program. The Runge-Kutta Method applies perfectly well to these systems of differential equations so it is necessary to write the equation in the matrix form:

$$
A \cdot \ddot{q}+C \cdot \dot{q}+B \cdot q=D
$$

where the correspnding matrices $A, B, C$ and $D$ are the functions of the generalized coordinates and speeds. The matrix $A$ is the mass (inertia) matrix,

$$
A=\left[\begin{array}{llllll}
a_{11} & a_{12} & a_{13} & a_{14} & a_{15} & a_{16} \\
a_{21} & a_{22} & a_{23} & a_{24} & a_{25} & a_{26} \\
a_{31} & a_{32} & a_{33} & a_{34} & a_{35} & a_{36} \\
a_{41} & a_{42} & a_{43} & a_{44} & a_{45} & a_{46} \\
a_{51} & a_{52} & a_{53} & a_{54} & a_{55} & a_{56} \\
a_{61} & a_{62} & a_{63} & a_{64} & a_{65} & a_{66}
\end{array}\right]
$$

The elements of the mass (inertia) matrix are symetric because the condition has been fulfilled:

$$
a_{i j}=a_{j i}
$$

The matrix $B$ is a rigidity matrix.

$$
B=\left[\begin{array}{cccccc}
b_{11} & b_{12} & b_{13} & 0 & 0 & 0 \\
b_{21} & b_{22} & b_{23} & 0 & 0 & 0 \\
b_{31} & b_{32} & b_{33} & 0 & 0 & 0 \\
0 & 0 & 0 & b_{44} & 0 & 0 \\
0 & 0 & 0 & 0 & b_{55} & 0 \\
0 & 0 & 0 & 0 & 0 & b_{66}
\end{array}\right]
$$

The matrix $D$ is an actuation forces matrix. 


$$
D=\left[\begin{array}{l}
d_{11} \\
d_{21} \\
d_{31} \\
d_{41} \\
d_{51} \\
d_{61}
\end{array}\right] .
$$

The matrix $\mathrm{C}$ is a damping matrix and it is hard to form it because $\dot{z}_{c}, \dot{\varphi}, \dot{\theta}, \dot{\alpha}, \dot{\beta}$ and $\dot{\gamma}$ are close-coupled and they are also close-coupled with $z_{c}, \varphi, \theta, \alpha, \beta$ and $\gamma$ making them almost impossible to split up. It is possible to make the systems of differential equations linear, and being taken as given, it would be possible to find out the matrix C. However, this does not have to be done, because resolving nonlinear equations is provided by MATLAB. Because of applying the MATLAB programme package it is necessary to write the equation in the matrix form:

$$
A \cdot \ddot{q}=-(C \cdot \dot{q}+B \cdot q-D)
$$

where it comes that:

$$
A=\left[\begin{array}{llllll}
a_{11} & a_{12} & a_{13} & a_{14} & a_{15} & a_{16} \\
a_{21} & a_{22} & a_{23} & a_{24} & a_{25} & a_{26} \\
a_{31} & a_{32} & a_{33} & a_{34} & a_{35} & a_{36} \\
a_{41} & a_{42} & a_{43} & a_{44} & a_{45} & a_{46} \\
a_{51} & a_{52} & a_{53} & a_{54} & a_{55} & a_{56} \\
a_{61} & a_{62} & a_{63} & a_{64} & a_{65} & a_{66}
\end{array}\right] \cdot\left[\begin{array}{c}
\ddot{z}_{C} \\
\ddot{\varphi} \\
\ddot{\theta} \\
\ddot{\alpha} \\
\ddot{\beta} \\
\ddot{\gamma}
\end{array}\right]=\left[\begin{array}{c}
s_{11} \\
s_{21} \\
s_{31} \\
s_{41} \\
s_{51} \\
s_{61}
\end{array}\right]
$$

From the previous it comes that:

$$
\ddot{q}=-A^{-1} \cdot S
$$


Or

$$
\left[\begin{array}{c}
\ddot{z}_{C} \\
\ddot{\varphi} \\
\ddot{\theta} \\
\ddot{\alpha} \\
\ddot{\beta} \\
\ddot{\gamma}
\end{array}\right]=A^{-1} \cdot\left[\begin{array}{l}
s_{11} \\
s_{21} \\
s_{31} \\
s_{41} \\
s_{51} \\
s_{61}
\end{array}\right]
$$

where the matrix $S$ is the column

$$
-S=\left[\begin{array}{l}
S_{11} \\
S_{21} \\
S_{31} \\
S_{41} \\
S_{51} \\
S_{61}
\end{array}\right]
$$

It is possible to resolve accelerations and speeds prepared in this way with the MATLAB programme package with variable changes done beforehand as following:

$$
\begin{aligned}
& x_{1}=z_{C}, x_{2}=\dot{z}_{C}, x_{3}=\varphi, x_{4}=\dot{\varphi}, x_{5}=\theta, x_{6}=\dot{\theta} \\
& x_{7}=\alpha, x_{8}=\dot{\alpha}, x_{9}=\beta, x_{10}=\dot{\beta}, x_{11}=\gamma, x_{12}=\dot{\gamma}
\end{aligned}
$$

The form of the system of differential equations looks like this:

$$
A\left(z_{c}, \varphi, \theta, \alpha, \beta, \gamma\right) \cdot\left[\begin{array}{c}
\ddot{z}_{C} \\
\ddot{\varphi} \\
\ddot{\theta} \\
\ddot{\alpha} \\
\ddot{\beta} \\
\ddot{\gamma}
\end{array}\right]=S\left(z_{c}, \varphi, \theta, \alpha, \beta, \gamma, \dot{z}_{c}, \dot{\varphi}, \dot{\theta}, \dot{\alpha}, \dot{\beta}, \dot{\gamma}\right)
$$

and is transformed into the system of twelve differential equations of the first kind making it suitable for numerical resolving by applying the MATLAB programme package. 


\section{Determining the dynamic behaviour of hydraulic excavators}

Resolving equation systems (3) used for describing the dynamic behaviour of the hydraulic excavator can be divided into:

- determinig natural frequencies and oscillation types

- determining the vectors of mobility $q_{i}\left(q_{i}=z_{c}, \varphi, \theta, \alpha, \beta, \gamma\right)$.

\section{Determining natural values}

Vibration issues are mostly connected with resonance, where one or more forms of vibration are activated by work power forces. Vibration forms lying among dynamic work forces' frequency levels are always a potential threat to cause problems. The modal analysis makes it possible to determine frequencies that may cause resonance to appear. The modal analysis is the process of determining all modal parametres sufficient for formulating a mathematical-dynamic model. The modal parametres are: modal frequencies, modal dampings and modal shapes. One of the very important mode properties is that any forced or free structure response may be brought together in one set of modes (Batinić, 2013), (Den Hartog, 1972).

Natural system values, i.e. natural frequencies and the corresponding vectors - modal forms - will be obtained through the free vibration system analysis while considering the homogeneous part of equation (3):

$$
A \cdot \ddot{q}+B \cdot q=0
$$

For the purpose of mathematical modelling of the free system vibrations, the aim of which is to determine their own values, it could be assumed that damping $\mathrm{C}$ within the system is negligible. According to the well-known procedure for determining the equation system own values (3), the dynamic matrix $U$ is formed together with its characteristic determinant, i.e. a characteristic system equation:

$$
\operatorname{det}(\lambda \cdot I-U)=0
$$

where:

- $U=A^{-1} \cdot B$ - the dynamic system matrix where $\mathrm{A}$ and $\mathrm{B}$ are the inertia matrix and the system rigidity matrix,

- unit matrix, 
- $\lambda=\frac{1}{\omega^{2}}$ - i.e. $\omega$ is the system natural frequency.

The observed hydraulic excavator is described by means of the system of nonlinear differential equations meaning that the system dynamic properties cannot be taken as constants. It applies in the same way to both rigidity and damping coefficients and their matrices coefficients. In such cases, it is not possible to make any separations based on their characteristic forms, by means of the vertical coordinates into a set of independent equations. A possibility of a step-by-step numerical integration is used for this kind of analysis - for certain time interval, the system is cosidered as linear with the characterisitcs it had at the beginning of that time interval. So, a nonlinear analysis is approximated by the series of variable gradual system analyses (Batinić, 2000).

The matrix $U$ own values are zeros of the matrix $U$ characteristic polynomial i.e. the roots of the characteristic equation (13). In order to obtain own values and their corresponding vectors, we considered the system parametres at a certain point of time, taken from the results of the numerical system analysis of differential equations at a certain point of time, for example at a point of time $t=0.100 \mathrm{~s}$, i.e. in iteration $n=19999$

at a small initiative system motion. This is a necessity because the mass matrices and the system rigidities are subordinate to the generalized coordinates and their speeds, and as such they cannot be used for obtaining dynamic system matrices. The matrices of rational values were obtained by this procedure (Jovanović et al, 2004). The system state vector is shown in Table 1.

Table 1 - System State Vector

Таблица 1 - Вектор состояния системы

Табела 1 - Вектор стања система

\begin{tabular}{|c|c|c|c|c|c}
\hline$z_{c}$ & $\dot{z}_{c}$ & $\varphi$ & $\dot{\varphi}$ & $\theta$ & $\dot{\theta}$ \\
\hline-0.0022 & 0.0913 & -0.0010 & -0.9068 & -0.0013 & 0.0105 \\
\hline
\end{tabular}

\begin{tabular}{|c|c|c|c|c|c|}
\hline$\alpha$ & $\dot{\alpha}$ & $\beta$ & $\dot{\beta}$ & $\gamma$ & $\dot{\gamma}$ \\
\hline 0.0049 & -0.1762 & -0.0903 & -3.2058 & 0.0398 & 8.7507 \\
\hline
\end{tabular}

The inertia matrix $A$ and the rigidity matrix $B$ of the system at the determined point of time are: 
$A=1.0 e+0.04 \cdot\left[\begin{array}{cccccc}1.0633 & 0.9423 & -0.2444 & -1.5645 & -0.2090 & 0.0080 \\ 0.9423 & 6.6536 & -0.3062 & -5.8923 & -1.8336 & 0.8307 \\ -0.2444 & -0.3062 & 4.1787 & 0.4836 & 0.0661 & -0.0009 \\ -1.5645 & -5.8923 & 0.4836 & 9.1443 & 1.3128 & -0.3437 \\ -0.2090 & -1.8336 & 0.0661 & 1.3128 & 0.8656 & -0.3928 \\ 0.0080 & 0.8307 & -0.0009 & -0.3437 & -0.3928 & 0.4432\end{array}\right]$

$$
B=1.0 e+0.08 \cdot\left[\begin{array}{cccccc}
0.600 & 0 & -0.6120 & 0 & 0 & 0 \\
0 & 1.6869 & -0.9890 & 0 & 0 & 0 \\
-0.6120 & -0.9890 & 2.4970 & 0 & 0 & 0 \\
0 & 0 & 0 & 0.1169 & 0 & 0 \\
0 & 0 & 0 & 0 & 0.0056 & 0 \\
0 & 0 & 0 & 0 & 0 & 0.0038
\end{array}\right]
$$

Applying the function $[V, D]=e i g(U)$ from the MATLAB programme package will make it possible to obtain the diagonal matrix $D$ containing own values on the main diagonal. We also obtained the full matrix $\mathrm{V}$ whose columns are the corresponding matrix $U$ vectors.

$$
\begin{aligned}
D & =1.0 e+0.04 \cdot\left[\begin{array}{cccccc}
1.4791 & 0 & 0 & 0 & 0 & 0 \\
0 & 0.8468 & 0 & 0 & 0 & 0 \\
0 & 0 & 0.2449 & 0 & 0 & 0 \\
0 & 0 & 0 & 0.0281 & 0 & 0 \\
0 & 0 & 0 & 0 & 0.0130 & 0 \\
0 & 0 & 0 & 0 & 0 & 0.0041
\end{array}\right] \\
V & =\left[\begin{array}{ccccccc}
-0.1588 & -0.8613 & -0.6478 & -0.0059 & -0.0169 & 0.0071 \\
-0.5614 & 0.2806 & -0.3303 & -0.0034 & -0.0115 & 0.0088 \\
0.1679 & 0.1327 & -0.4723 & -0.0027 & -0.0082 & 0.0051 \\
-0.2906 & -0.0266 & -0.2479 & 0.1243 & 0.2179 & -0.0655 \\
-0.7119 & 0.2957 & -0.4279 & -0.6816 & 0.1570 & -0.7386 \\
0.2004 & -0.2715 & 0.0603 & -0.7210 & 0.9630 & 0.6708
\end{array}\right] .
\end{aligned}
$$


The range of natural frequencies was obtained by finding the square root of the diagonal matrix $\mathrm{D}$ solution and dividing it by $2 \pi$ (Table 2 ).

Table 2 - Natural frequencies

Таблица 2 - Eстественные частоты

Табела 2 - Сопствене фрреквенције

\begin{tabular}{|c|c|c|c|c|c|c|}
\hline $\begin{array}{c}\text { Natural } \\
\text { frequenci } \\
\text { es }\end{array}$ & $\omega_{Z c}$ & $\omega_{\varphi}$ & $\omega_{\theta}$ & $\omega_{\alpha}$ & $\omega_{\beta}$ & $\omega_{\gamma}$ \\
\hline $\mathrm{rad} / \mathrm{s}$ & 121.6164 & 92.0227 & 49.4916 & 16.7553 & 11.4087 & 6.4191 \\
\hline $\mathrm{Hz}$ & 19.3558 & 14.6459 & 7.8768 & 2.6667 & 1.8158 & 1.0216 \\
\hline
\end{tabular}

The natural frequencies for the state vector of equal system activation with the time of $t=0.025 \mathrm{~s}$ and the iteration of 4999 were calculated as shown in Table 3.

Table 3 - Natural frequencies

Таблица 3 - Eстественные частоты

Табела 3 - Сопствене фрреквенције

\begin{tabular}{|c|c|c|c|c|c|c|}
\hline $\begin{array}{c}\text { Natural } \\
\text { frequencies }\end{array}$ & $\omega_{Z c}$ & $\omega_{\varphi}$ & $\omega_{\theta}$ & $\omega_{\alpha}$ & $\omega_{\beta}$ & $\omega_{\gamma}$ \\
\hline $\mathrm{rad} / \mathrm{s}$ & $0+131.90 i$ & 96.16 & 78.41 & 47.39 & 14.12 & 8.62 \\
\hline $\mathrm{Hz}$ & $0+20.9918 i$ & 15.3041 & 12.4792 & 7.5420 & 2.2474 & 1.3718 \\
\hline
\end{tabular}

\section{Determining motion vectors on the generalized coordinates}

Differential equations were resolved by applying the MATLAB packet programme, and the generalized coordinates of free oscillation models and their derivatives for the time $t=0.1 \mathrm{~s}$ were obtained as well. The simulation of the observed hydraulic excavator behaviour was done at the beginning of moving the soil away, after the excavation of the soil had been finished with the angles of $\alpha_{0}=-35^{\circ}, \beta_{0}=-80^{\circ}$ and $\gamma_{0}=160^{\circ}$ together with the angle $\psi=90^{\circ}$ regarded as the most unfavourable for excavator operations. The initial movements were very near zero. The simulation results are shown in Figures $5-10$. 


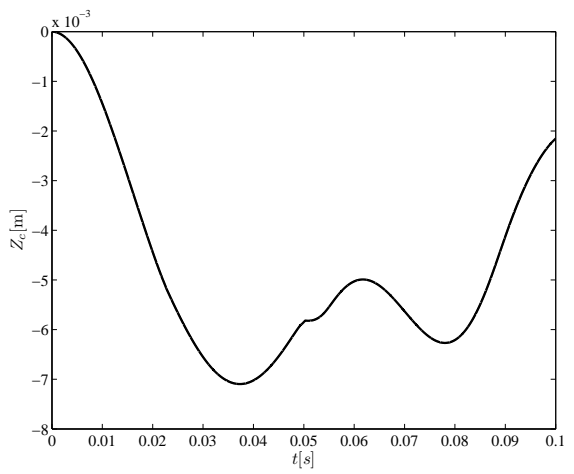

Figure 5 - Vertical motion of the undercarriage mass center $-z_{c}$

Puc. 5 - Вертикальное перемещение центра массы опорно-ходового

$$
\text { устройства }-z_{c}
$$

Слика 5 - Вертикално померање средишта масе ослоно-кретног

$$
\text { члана }-z_{c}
$$

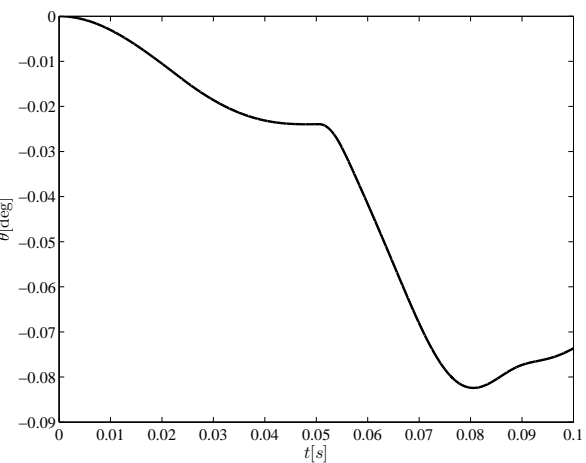

Figure 7-Angle of the undercarriage rotation around the transversal main cental axis of inertia $O_{1} y_{1}-\theta$

Puc. 7 - Угол поворота опорноходового устройства вокруг поперечной главной центральной оси инерции $O_{1} y_{1}-\theta$

Слика 7 - Угао обртања ослонокретног члана око попречне главне централне осе инерције $O_{1} y_{1}-\theta$

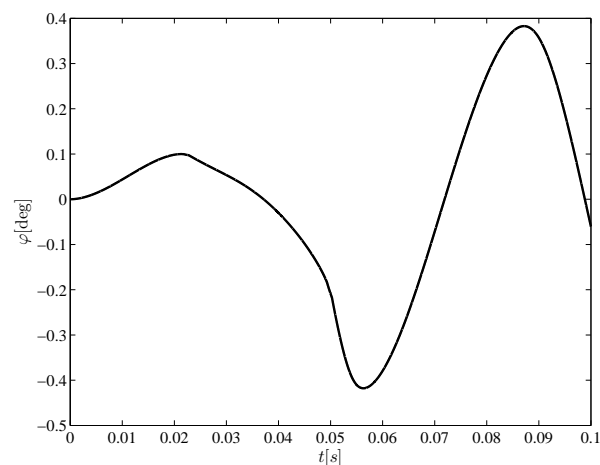

Figure 6 - Angle of the undercarriage rotation around the longitudinal main central axis of inertia $O_{1} x_{1}-\varphi$

Puc. 6 - Угол поворота опорно-ходового устройства вокруг продольной главной центральной оси инерции $O_{1} x_{1}-\varphi$

Слика 6 - Угао обртања ослоно-кретног члана око уздужне главне централне осе инерције $O_{1} x_{1}-\varphi$

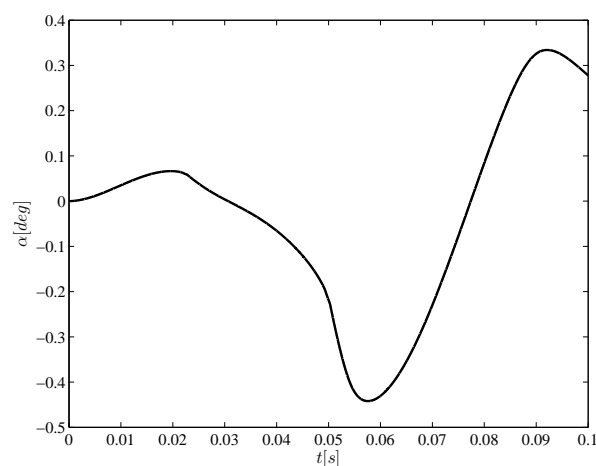

Figure 8 - Angle of the boom rotation of the manipulator around the axis $O_{3} y_{3}-\alpha$

Puc. 8 - Угол поворота срелы манипулятора вокруг оси $\mathrm{O}_{3} y_{3}-\alpha$

Слика 8 - Угао обртања стреле манипулатора око осе $\mathrm{O}_{3} y_{3}-\alpha$ 


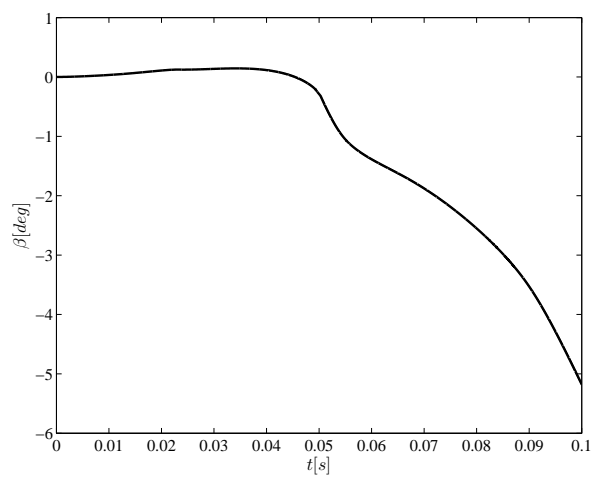

Figure 9-Angle of the arm rotation of the manipulator around the axis $O_{4} y_{4}$ of the joint in the end of the boom - $\beta$

Рис. 9 - Угол вращения рукояти манипулятора вокруг оси $\mathrm{O}_{4} y_{4}$ шарнира на конце стрелы - $\beta$

Слика 9 - Угао обртања руке манипулатора око осе $\mathrm{O}_{4} y_{4}$ зглоба на крају стреле - $\beta$

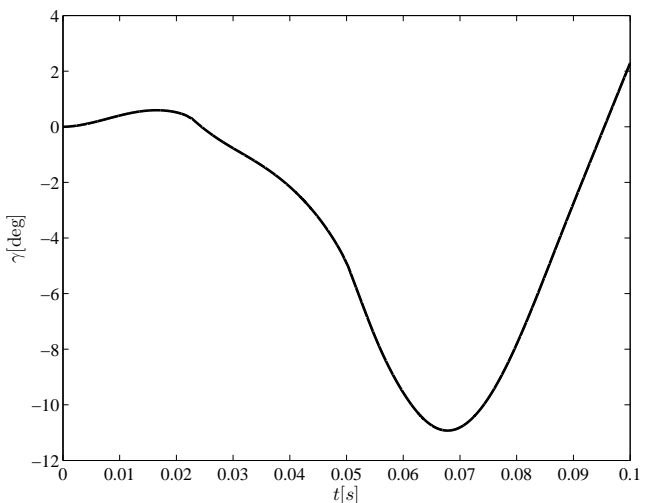

Figure 10-Angle of the bucket rotation of the manipulator around the axis $O_{5} y_{5}$ of the joint in the end of the arm - $\gamma$

Pис. 10 - Угол вращения ковша манипулятора вокруг оси $O_{5} y_{5}$ шарнира на конце рукояти

Слика 10 - Угао обртања кашике манипулатора око осе $O_{5} y_{5}$ зглоба на крају руке - $\gamma$

\section{Results analysis}

The observed hydraulic excavator system was activated by a very small initial value of one of the generalized coordinates. This possibility is allowed by the simulation programme package. That way, the system is exposed to free oscillations. This state is described by homogeneous nonlinear differential equations.

The natural frequencies obtained by the mathematical model based on the generalized coordinate $z$ have the values of $\omega_{z c}=19.3558 \mathrm{~Hz}$ and $\omega_{z c}=0+20.9918 i$. These frequencies on the $z$ axis have the biggest impact on the excavator operator. When compared with some resonant frequencies [3-20Hz] it is possible to claim that, for some human organs, they partially overlap. This could cause problems to the operator in case of being in action over a longer period of time.

By analyzing the previously described numerical experiments, it is clear that some kinds of movement freedom, i.e. generalized coordinates, generate free oscillations of certain frequencies that do not allow the 
system to easily calm down after the initiative activation time. It was even proved that, with only one activation, within the observed time interval, at one iterration only, the system has free oscillations of one degree of freedom, and that at the second iterration it has free socillations of another degree of freedom. All these facts clearly indicate that the system is dynamically unstable or at least on the very edge of the stability reference values. The described fenomenon of free oscillation is proved on the generalized coordinate $z_{c}$.

Figure 5 shows the nature of the vertical movement of the undercarriage mass center. It is clear that the oscillation amplitudes are within the tolerable limits and that they gradually go down with the system tending to calm down.

Figure 6 shows the nature of the rotation angle change $\varphi$ around the undercarriage longitudinal axis. The oscillation amplitude is tolerable, but there is no evidence of its going up or down within the observed interval of simulation.

Figure 7 illustrates the rotation angle change $\theta$ around the transversal undercarriage axis $O_{1} y_{1}$. The oscillation amplitude is within tolerable limits, but like in the previous case, there is no evidence of the amplitude tending to go up or down within the observed interval of simulation.

The change of the rotation angle of the manipulator boom $\alpha$ around the axis $\mathrm{O}_{3} y_{3}-\alpha$ inside the joint connecting the manipulator and the undercarriage is described in Figure 8. The oscillating nature of this angle's change within the observed time interval is obvious, but with the amplitude tending to go down.

Figure 9 shows the change in the rotation angle of the manipulator arm $\beta$ around the axis $O_{4} y_{4}$ of the joint in the end of the boom. The displayed change is not oscillatory, in the observed time, and it has a tendency to grow up to unacceptable values. This tendency is conditioned by free oscillation of the excavator in the generalized coordinates $z$.

Figure 10 shows the change in the bucket rotation angle of the manipulator $y$ around the axis $O_{5} y_{5}$ of the joint in the end of the arm. The displayed change has the oscillatory character with an increased amplitude value. In the observed simulation time, the tendency to a reduced or increased amplitude cannot be estimated.

The graphics of the generalized coordinates in Figures 9 and 10 do not show the system calm down within the observed time interval because the system is within the unstability area or on the very edge of the stability reference values, which was caused by free system oscillation on one of 
the generalized coordinates. Because of this, immediately after the time of $t=0.1 \mathrm{~s}$ the system gets into resonance with a significantly increased oscillation amplitude. In order to get the system calm down, i.e. to make the oscillation amplitudes on all generalized coordinates reach lower values, preferably zero, all real parts of the characteristic system equation square roots ought to be negative. This precondition for the observed excavator has not been met.

\section{Conclusion}

This paper deals with the analysis of the dynamic behaviour of hydraulic excavators. By applying the dynamic-mathematical model, we determined the level and nature of dynamic motions and natural frequencies. An excavator operator is a person who is seated in the rotating platform. System vibrations reach him via the excavator backing. This predominantly refers to the vibrations on the generalized coordinate $z_{c}$, which is a longitudinal direction, i.e. the direction of the operator's backbone and that is why exposure to these vibrations was addressed to with special attention. Besides these vibrations, the operator is exposed to the vibrations on the generalized coordinates $\varphi$ and $\theta$ which additionally makes the situation more complicated and increases possible harmful impacts on the operator's health. The hydraulic excavator natural frequency values, derived from analytical calculations, prove the intensity so high that it might cause serious problems to the operator's health. By comparing the natural frequency intensity values on the generalized coordinates $\theta, \varphi$ and $\theta$ with the resonance frequencies for some human organs, the possibility of serious harmful effects is obvious.

Describing the hydraulic excavator dynamic behaviour by the system of nonlinear, nonhomogenous differential equations made it possible to improve the analytical-mathematical model by which a simulated situation is almost like a real life situation of an excavator in operation.

By applying the modal analysis, it was possible to determine certain system frequencies and their corresponding vectors which might cause resonance to appear and thus spoil the operator's working condition comfort.

The numerical analysis was carried out for the BTH-600 excavator structure. The obtained results indicate that the structure was not composed at its best and that a dynamic analysis should be used to improve the dynamic characteristics of the observed system. 


\section{References}

Batinić, V. 2013. Planetary gear dynamic response to mesh parametric excitation. Vojnotehnički glasnik / Military Technical Courier, 61(1), pp.58-68 (in Serbian). Available at: http://dx.doi.org/10.5937/vojtehg61-2006.

Batinić, V. 2000. Unutrašnja dinamika opterećenja planetarnih prenosnika, MSc thesis, University of Belgrade: Faculty of Mechanical Engineering (in Serbian).

Den Hartog, J.P., 1972. Vibracije u mašinstvu. Beograd: Građevinska knjiga (in Serbian).

Frimpong, S., Hu, Y. \& Inyang, H. 2008. Dynamic Modeling of Hydraulic Shovel Excavators for Geomaterials.International Journal of Geomechanics, 8(1), pp.20-29. Available at: http://doi.org/10.1061/(ASCE)15323641(2008)8:1(20).

Holclajtner, M., Jeremić, O. \& Milinović, M. 2010. Simulacija rafala višecevnog bacača raketa. Vojnotehnički glasnik/Military Technical Courier, 58(2), pp.5-25 (in Serbian). Available at: http://doi.org/10.5937/vojtehg1002005H.

Janošević, D. 1997. Optimalna sinteza pogonskih mehanizama hidrauličkih bagera, Ph.D. thesis, University of Niš: Faculty of Mechanical Engineering (in Serbian).

Jovanović, M., Janošević, D. \& Milić, P. 2004. Modalna fem analiza kostura kretnog mehanizma hidrauličkog bagera. In: Naučno-stručni skup Istraživanje $i$ razvoj mašinskih elemenata i sistema, IRMES, Kragujevac (in Serbian).

Lazarević, D. 2003. Inžinjerijske mašine 1. Belgrade: Vojna akademija Generalštab Vojske Srbije i Crne Gore - Uprava za školstvo i obuku (in Serbian).

Lazarević, O., Batinić, V. \& Ranđelović, A. 2014. Određivanje brzina karakterističnih tačaka hidrauličkog bagera. In: 4. međunarodna konferencija za geometriju i grafiku moNGeometrija, Vlasina (in Serbian).

Lazarević, O., Krsmanović, M. \& Perić, S. 2008. Analysis of dynamic behavior generators of hydraulic excavator. In: Kongres MVM, Kragujevac.

Vähä, P.K. \& Skibniewski, M.J. 1993. Dynamic Model of Excavator. Journal of Aerospace Engineering, 6(2), pp.148-158. Available at: https://doi.org/10.1061/(ASCE)0893-1321(1993)6:2(148).

\section{ОПРЕДЕЛЕНИЕ ДИНАМИЧЕСКИХ ПАРАМЕТРОВ ГИДРАВЛИЧЕСКИХ ЭКСКАВАТОРОВ}

Олгица Ж. Лазаревич ${ }^{\text {, Боро М. Лазаревич }}$

а Университет обороны в г. Белград, Кафедра военно

машиностроительного инжиниринга, г. Белград, Республика Сербия

б Китайская компания коммуникаций и строительства, г. Белград,

Республика Сербия 
ОБЛАСТЬ: машиностроение

ВИД СТАТЬИ: оригинальная научная статья

ЯЗЫК СТАТЬИ: английский

\section{Резюме:}

В данной работе представлены исследования динамических параметров гидравлического экскаватора: естественные частоты и движение. Работа экскаватора описана путем математических моделей с шестью обобщенными координатами, полученными на основании уравнений Лагранжа второго рода. Разработанная математическая модель системы экскаватора представляет собой систему нелинейных неоднородных диффреренциальных уравнений второго рода. С помощью моделирования с реальными значениями параметров получены функции изменений движения и естественной частоты при допустимых степенях свободы, благодаря чему можно провести анализ характера и интенсивности движения, воздействия этих параметров на машиниста и оптимизировать конструкцию экскаватора (изменение массы, жесткости и демпфирования).

Ключевые слова: гидравлический экскаватор, динамические характеристики, математическая модель, естественные частоты, движение.

\section{ОДРЕЂИВАЊЕ ДИНАМИЧКИХ КАРАКТЕРИСТИКА} ХИДРАУЛИЧКИХ БАГЕРА

Олгица Ж. Лазаревић ${ }^{a}$, Боро М. Лазаревић ${ }^{6}$

а Универзитет одбране у Београду, Војна академија,

Катедра војномашинског инжењерства, Београд, Република Србија

${ }^{\sigma}$ China Communication Construction Company, Београд, Република Србија

ОБЛАСТ: машинство

ВРСТА ЧЛАНКА: оригинални научни чланак

ЈЕЗИК ЧЛАНКА: енглескИ

\section{Сажетак:}

У раду су приказана истраживања динамичких карактеристика хидрауличких багера: сопствене фрреквениије и померања. Рад багера описан је математичким моделом са шест генералисаних координата који је добијен применом Лагранжевих једначина друге врсте. Добијени математички модел система багера представља систем од шест нелинеарних нехомогених дифреренцијалних једначина другог 
реда. Симулацијом са реалним вредностима параметара добијене су функције промене померања и сопствене фреквенције по дозвољеним степенима слободе, umo омогућава испитивање карактера и интензитета тих померања, утицаја параметара на руковаоца багера и оптимизацију конструкције багера (промене маса, крутости и пригушења).

Кључне речи: хидраулички багер, динамичке карактеристике, математички модел, сопствене фреквенције, померање.

Paper received on / Дата получения работы / Датум пријема чланка: 30.06.2017.

Manuscript corrections submitted on / Дата получения исправленной версии работы / Датум достављања исправки рукописа: 26.11.2017.

Paper accepted for publishing on / Дата окончательного согласования работы / Датум коначног прихватања чланка за објављивање: 28.11.2017.

(C) 2018 The Authors. Published by Vojnotehnički glasnik / Military Technical Courier (www.vtg.mod.gov.rs, втг.мо.упр.срб). This article is an open access article distributed under the terms and conditions of the Creative Commons Attribution license (http://creativecommons.org/licenses/by/3.0/rs/).

() 2018 Авторы. Опубликовано в «Военно-технический вестник / Vojnotehnički glasnik / Military Technical Courier» (www.vtg.mod.gov.rs, втг.мо.упр.срб). Данная статья в открытом доступе и распространяется в соответствии с лицензией «Creative Commons» (http://creativecommons.org/licenses/by/3.0/rs/).

() 2018 Аутори. Објавио Војнотехнички гласник / Vojnotehnički glasnik / Military Technical Courier (www.vtg.mod.gov.rs, втг.мо.упр.срб). Ово је чланак отвореног приступа и дистрибуира се у складу са Creative Commons licencom (http://creativecommons.org/licenses/by/3.0/rs/).

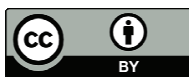

